\title{
Evaluation and preparation of guava jam stored at ambient temperature
}

\author{
Talmiz Ur Rahman ${ }^{1}$, Amanullah $^{2}$, Nazia Tahir ${ }^{2 *}$, Said wahaab ${ }^{3}$, \\ AdnanTahir ${ }^{4}$, Ata Ur Rahman ${ }^{3}$ and Arsalan Khan ${ }^{5}$ \\ 1. Beijing Technology and Business University, Beijing-China \\ 2. Department of Agriculture, Abdul Walikhan University Mardan-Pakistan \\ 3. Department of Food Science, University of Agriculture Peshawar-Pakistan \\ 4. Department of Agriculture, University of Swabi-Pakistan \\ 5. Agriculture Research Institute, Tarnab Farm Peshawar KPK-Pakistan \\ *Corresponding author's email: naziatahir10@gmail.com
}

Citation

Talmiz Ur Rahman, Nazia Tahir, Amanullah, Said wahaab Ata Ur Rahman, Arsalan Khan and Adnan Tahir.

Evaluation and preparation of guava jam stored at ambient temperature. Pure and Applied Biology. Vol. 7, Issue 3, pp1064-1073. http://dx.doi.org/10.19045/bspab.2018.700125

\begin{tabular}{llll}
\hline \hline Received: 26/04/2018 & Revised: 25/07/2018 & Accepted: 27/07/2018 & Online First: 04/08/2018 \\
\hline \hline
\end{tabular}

\section{Abstract}

The research work was on the effect of pectin on the textural property and storage stability of guava fruit jam stored at ambient temperature. The research was conducted at ARI, Tarnab, Pakistan in the lab of Food Technology section. The aim of the study was to study the effect of storage stability of guava fruit jam when stored at ambient temperature. The treatment was design with 1:1 ratio of guava pulp and sugar with different level of pectin content. All the treatments were studied physico-chemically and sensor ally for 90 days with 15 days' interval. The increased was observed in TSS of Guava fruits jam from, \% acidity and reducing sugars. It was found from statistical analysis that the value of non-reducing sugar of the jam reduced considerably $(\mathrm{p}<0.05)$ during 90 days of storage interval. While decreased was observed in $\mathrm{pH}$ (3.61 to 3.44), nonreducing sugars (42.95 to $23.45 \%$ ), Ascorbic acid (92.8 to $71.52 \mathrm{mg} / 100 \mathrm{~g}$ ), color score (7.1 to 4.31), taste score (7.60 to 4.71 ), texture score (7.21 to 4.41 ) and acceptability score (7.51 to 4.65 ). The mean sensory scores for texture of the jam decreased significantly $(\mathrm{p}<0.05)$ on both treatments and storage intervals. The $\mathrm{pH}$ value decrease significantly, the high acidity of fruit jam might be due to the hydrolysis of starch to acid. Storage intervals and treatments significantly $(\mathrm{p}<0.05)$ affect the color of guava jam during storage interval. Further studies need to be done to study the effect of storage on jam preservation and quality effects.

Keywords: Ambient Temperature; Guava frui; Jam; Pectin

\section{Introduction}

Guava (psidiumguajavalinn) belongs to the family myrtaceae and is one of the most gregarious fruit trees. Guava is believed to be originated in tropical America (Mexico to Peru). Now it is the main products of south Asian countries, like the Hawaiian island, Cuba, brazil, Pakistan and India [1].Guava is widely grown all over the tropics and subtropics though origin of guava is the tropical America but in this sub-continent, guava has been in cultivation since early 17 th century [2]. It is cultivated less or more in Pakistan, that's why it is one of the major fruit of Pakistan. In Pakistan, cities like Lahore, Faisalabad (Punjab province), Hyderabad, 
Larkana (Sindh province), Kohat, Haripur, Mardan, Charsadda, Swabi and Malakand (Khyber Pakhtunkhwa) are very famous for producing best quality of guava [3]. In Pakistan 65.1('000' hectares) area are under guava cultivation, which includes 52.9('000' hectares) in Punjab, 9.6('000' hectares) in Sindh, 2.1('000' hectares) in Khyber Pakhtunkhwa and 0.5('000' hectares) in Baluchistan and total production was 495.2 ('000'tonnes) which includes 377.6('000'tonnes) in Punjab, 71.9 ('000'tonnes) in Sindh, 42.9('000'tonnes) in Khyber Pakhtunkhwa and 2.8 ('000'tonnes) in Baluchistan [4].

Guava is a rich source of primary metabolites and secondary metabolites like ascorbic acid, proteins, carbohydrates, pectin, minerals, calcium and phosphorus [5]. Fruit contains high amount of ascorbic acid (88.2 to 250.8 $\mathrm{mg} / 100 \mathrm{~g})$, vitamin A (200 to $400 \mathrm{Iu})$, lycopene $(45.3 \mu \mathrm{g} / \mathrm{g})$, reducing sugars $(2.05$ to $6.08 \%$ ), total sugars (10 to $15.3 \%$ ), acids (10 to $15.3 \%)$, pectins $(0.62 \%)$ and phenols (170 to $345 \mathrm{gae} / \mathrm{g} \mathrm{fw}$ ) (kaur et al., 2009). The level of ascorbic acid content of guava is higher than any other fruits even from citrus fruit $(91-266.8 \mathrm{mg} / 100 \mathrm{~g})$ observed by $[6,7]$. No foreign plant tissue was found in any sample when compared to authentic fruit tissues. Guava are usually eaten as fresh and sweet fruit that is pleasant and refreshing in taste [8]. Skin is also eaten along with pulp [9]. It is records as pleasant and juicy fruits. Guava fruit can be used in making of pudding, salads, jam, jelly, canned fruit, cheese, RTS, nectar, squash, toffees and ice cream by $[10,11]$. Guava is also called the poor's man apple. Tropic area has a long history of traditional use, much of which is being validated by scientific research [12]

Jam is distinct as semi-solid mixture, obtained upon cooking the fruit soft tissue with sugar. Jam is an in-between moisture food prepared by boiling fruit pulp with sugar (sucrose), pectin, acid and other ingredients (additive, coloring, and flavoring materials) to a rationally thick evenness, firm enough to grip the fruit tissues in position. Jam should enclose more than $68.5 \%$ total soluble solids (TSS) plus at least $45 \%$ fruit whereas, the codex alimentations commission identify that the finished jam be supposed to contain more than $65 \%$ TSS. The highest stability of the anthocyanins was found when the jams were stored at fridge temperature $\left(4^{\circ} \mathrm{C}\right)$. The traditional jam showed higher stability than the pressured jams but also a bigger loss of anthocyanins during the production process [13]. Jam made from lye peeled segment did not develop bitterness whereas unpeeled segment developed bitterness [14]. In jam production, pectin can be obtained from fruit peels like orange which increases the dietary fiber of the end product and also reduces blood sugar when consume[15].

\section{Materials and methods}

This research was conducted in the Agriculture Research Institute Tarnab Farm, Peshawar Pakistan. Sound healthy guava fresh fruits were purchased from the local market of Peshawar. The fruit was first washed with tape water in order to removed dust and rust particle. Coring and cutting was carried out using stainless steel knife. After cutting the fruit was put in to $0.1 \%$ citric acid solutions individually to prevent discoloration. The guava fruit pulp was extracted through pulper machine. The pulp along with other ingredients was transferred to the steam kettle. The cooking proceeded until the usual consistence adopted by industry, which was confirmed by refractometer. These preservative was added individually to each treatment. Each sample was stored in the glass jars at ambient temperature. Storage temperature had a strong influence on anthocyanin degradation. As the storage temperature increased, the stability of anthocyanins decreased significantly in both colored and no colored jams [16]. 


\section{Plan of study}

Treatment with concentration of pectin

$\mathrm{T} 0=50 \%$ guava pulp $+50 \%$ sugar + no Pectin $+5 \mathrm{gm} / \mathrm{kg} \mathrm{c.a}+1 \mathrm{gm} / \mathrm{kg} \mathrm{s.b}$

$\mathrm{T} 1=50 \%$ guava pulp $+50 \%$ sugar $+.2 \%$

Pectin $\%+5 \mathrm{gm} / \mathrm{kg} \mathrm{c.a}+1 \mathrm{gm} / \mathrm{kg} \mathrm{s.b}$

$\mathrm{T} 2=50 \%$ guava pulp $+50 \%$ sugar +.4 Pectin $\%$

$+5 \mathrm{gm} / \mathrm{kg} \mathrm{c.a}+1 \mathrm{gm} / \mathrm{kg} \mathrm{s.b}$

$\mathrm{T} 3=50 \%$ guava pulp $+50 \%$ sugar +.6 Pectin

$\%+5 \mathrm{gm} / \mathrm{kg} \mathrm{c.a}+1 \mathrm{gm} / \mathrm{kg} \mathrm{s.b}$

$\mathrm{T} 4=50 \%$ guava pulp $+50 \%$ sugar+. 8 Pectin

$\%+5 \mathrm{gm} / \mathrm{kg} \mathrm{c.a}+1 \mathrm{gm} / \mathrm{kg} \mathrm{s.b}$

T5 $=50 \%$ guava pulp $+50 \%$ sugar +1 Pectin $\%$

$+5 \mathrm{gm} / \mathrm{kg} \mathrm{c.a}+1 \mathrm{gm} / \mathrm{kg} \mathrm{s.b}$

T6 $=50 \%$ guava pulp $+50 \%$ sugar $+1.2 \%$

Pectin $+5 \mathrm{gm} / \mathrm{kg}$ c.a $+1 \mathrm{gm} / \mathrm{kg}$ s.b

\section{Physicochemical analysis}

Physico-chemically all the treatment was analyzed for $\mathrm{pH}$, Titratable acidity, Total soluble solid, Ascorbic acid content, Reducing and non-reducing sugar according to the standard methods of [17].

\section{Sensory evaluation}

The sensory evaluation of guava jam was examined by 10 panel of trained judge. The sensorally the treatments were analyzed for color, texture, taste and overall acceptability at 15 days' interval for a total period of 90 days. The sensory evaluation was carried out by using 9 points hedonic scale of larmond.

\section{Statistical analysis}

All the data regarding treatments and storage were analyzed statistically by means of completely randomized design (CRD) 2 factorial and the means were separated by applying least significant difference (LSD) test at $5 \%$ possibility level as defined by [18].

\section{Result and discussion}

\section{Total soluble solid (TSS)}

The total soluble solid content of different of guava jam was 67.5, 67.2, 67.6, 67.8, 67, 67.3 and 67.4 on the initial day of the storage (Table 1). While the default value for the jam prepared in different industries were 65 ${ }^{\circ}$ Brix. During 90 days storage period, the mean value of TSS of different treatment of guava jam gradually rises from 67.4 to 69.71 . Higher increase in percent was revealed in T0 $(3.84 \%)$ while the lower increase in percent was observed in T2 $(2.88 \%)$. Statistical results revealed that treatment and storage had a considerable effect $(\mathrm{P}<0.05)$ on the TSS of guava jam during 90 days of storage interval. The increase in total soluble solid of different treatment of guava jam was due to the conversion of complex carbohydrates to simple sugar. The present shows agreement to the other researcher who reported similar results in increase of total soluble solid during storage by [19-21] reported increasing trend from (68.5-71.2 brix) during storage of 90 days of pear apple jam and in mango jams remained organoleptically acceptable after 150 days storage reported by [22-24] observed an increase in soluble solid from (70-70.8 brix) of watermelon and lemon jam. It was also observed that in general the SKC score had increased by $[25,26]$.

\section{pH}

$\mathrm{pH}$ is consider an important factor during preparation of jam to obtain principal gel formation (Table 2). The $\mathrm{pH}$ value of the treatment at the initial day of storage was 3.7, $3.65,3.62,3.57,3.58,3.6$, and 3.61, which eventually decreased during 90 days of storage. The decreased in $\mathrm{pH}$ was best elaborated from the mean value of the storage as shown in (Table 2) from 3.61 to 3.44 . The maximum percent decreased was observed in treatment T0 $(5.94 \%)$ while the minimum percent decreased was founded in treatment T6 $(3.87 \%)$ during 90 days of storage. Statistical results revealed that treatment and storage had a considerable effect $(\mathrm{P}<0.05)$ on the $\mathrm{pH}$ value of guava jam during 90 days of storage interval. The decreased in $\mathrm{pH}$ value of guava jam was might be due to the contribution of hydrogen ions in acid formation, which leads to increase in acidity and decrease in $\mathrm{pH}$ value. These results are also supported by [27-29] who founded somewhat similar trend of decreased in $\mathrm{pH}$ 
value in apricot jam. Similarly, previous literature supported the present finding, as they also studied fall in the $\mathrm{pH}$ values of fruit jam during storage [30].

\section{Titratable acidity}

The percent acidity of the jam samples should not exceed $1 \%$, because above this level a phenomena occurs called syneresis (formation of water in the product) (Table 1). The values of acidity recorded in the present research study on the initial day were 0.76 , $0.74,0.7,0.69,0.73,0.71$, and 0.75 from T0 to $\mathrm{T} 6$, then shows gradual increase during 90 days of storage, but considered well below the limit of syneresis, thus results in reducing the possibility of defect in these treatment. The mean value shows the significant $(\mathrm{P}<0.05)$ increased in acidity from 0.72 to
0.89 during 90 days of storage. The higher percent increase was observed in treatment T2 $(25.29 \%)$ while the lower percent increase was founded in treatment T6 $(16.66 \%)$. The increasing trend of acidity in guava jam was might be due the conversion of pectic compound to pectic acid. These results are also supported by the findings of [31] who found an increase in percent acidity (0.65$0.70 \%$ ) of apricot jam during storage period. Similarly, the increase in acidity from 0.68 to 0.86 percent was observed in strawberry jam by $[32,33]$ also found an increase in percent acidity of the jam throughout storage interval. Similarly, [34] also found raise in acidity from 0.60 to $0.78 \%$ during storage. The high acidity of fruit jam might be due to the hydrolysis of starch to acid.

Table 1. Influence of treatments Means and storage intervals Means on total soluble solids of guava jam

\begin{tabular}{|c|c|c|c|c|}
\hline \multirow{2}{*}{\multicolumn{2}{|c|}{$\begin{array}{c}\text { Means Data } \\
\text { Treatments }\end{array}$}} & \multicolumn{3}{|c|}{$\%$ Increase } \\
\hline & & Titrable Acidity & TSS & Storage Interval \\
\hline & T0 & 0.85 & 68.64 & 23.55 \\
\hline & T1 & 0.81 & 68.34 & 23.5 \\
\hline & $\mathbf{T} 2$ & 0.77 & 68.61 & 21.98 \\
\hline & T3 & 0.76 & 68.85 & 22.12 \\
\hline & T4 & 0.80 & 68.08 & 21.85 \\
\hline & T5 & 0.78 & 68.30 & 23.41 \\
\hline & T6 & 0.82 & 68.38 & 21.26 \\
\hline \multicolumn{5}{|c|}{ Storage Interval Means } \\
\hline Days & 0 & 0.72 & 67.4 & 0.72 \\
\hline & 15 & 0.74 & 67.7 & 0.74 \\
\hline & 30 & 0.77 & 67.97 & 0.77 \\
\hline & 45 & 0.78 & 68.41 & 0.78 \\
\hline & 60 & 0.82 & 68.84 & 0.82 \\
\hline & 75 & 0.85 & 69.15 & 0.85 \\
\hline & 90 & 0.89 & 69.71 & 0.89 \\
\hline
\end{tabular}

LSD (0.05)

0.98

\section{Ascorbic acid}

Ascorbic acid content of the guava jam samples were determined at 15 days interval for a period of 90 days, to study the effect of storage on the stability and degradation of ascorbic acids. Results revealed the gradual decrease in the ascorbic acid concentration of all the treatment of guava jam as shown in the (Table 2). The initial day observed data were 90.17, 92.4, 95, 91.8, 92.13, 94.8, 93.3 $\mathrm{mg} / 100 \mathrm{~g}$ from Toto T6 respectively. The mean value of storage also of all the treatment 
decreases from $92.8 \mathrm{mg} / 100 \mathrm{~g}$ to $71.52 \mathrm{mg} / 100 \mathrm{~g}$. Maximum percent decrease was found in treatment T4 $(23.87 \%)$ while minimum percent decrease was observed in treatment T6 (20.90). Statistical finding also revealed that treatment and storage has a significant $(\mathrm{P}<0.05)$ effect on the ascorbic acid content of guava jam during 90 days of storage. This decrease in ascorbic acid content might be due the oxidation as well as catalytic reaction take place within the jam samples. The principal cause of ascorbic acid decreased might be due to the residual oxygen present in the head space of the jar. Upon oxidation the normal ascorbic acid will normally be converted to De-hydro ascorbic acid which also form de keto gluconic acid.
These findings are in agreement to [35] who observed similar trend of decrease in ascorbic acid content of strawberry jamfrom 18 $\mathrm{mg} / 100 \mathrm{~g}$ to $13 \mathrm{mg} / 100 \mathrm{~g}$ throughout the storage interval Similar trend of decline in ascorbic acid content of fruit jam was observed by [36, 37]. Mild processing caused lower color differences than common processing [38].The loss of ascorbic acid content is due to the effect of light in the storage environment of the product. Ascorbic acid is the most important nutrient that represents the quality characteristics of the product, which is substantially affected due to oxidation during processing and storage [39].

Table 2. Means on total soluble solids of guava jam

\begin{tabular}{|c|c|c|c|c|c|c|c|c|c|}
\hline \multirow{2}{*}{\multicolumn{2}{|c|}{$\begin{array}{c}\begin{array}{c}\text { Means } \\
\text { Data }\end{array} \\
\text { Treatments }\end{array}$}} & \multicolumn{8}{|c|}{$\%$ Decrease } \\
\hline & & $\begin{array}{c}\text { Non- } \\
\text { reducing } \\
\text { sugar }\end{array}$ & Taste & $\begin{array}{c}\text { Over all } \\
\text { capability }\end{array}$ & Texture & Color & $\begin{array}{l}\text { Reducing } \\
\text { sugar }\end{array}$ & $\begin{array}{c}\text { Vitamin } \\
\mathrm{C}\end{array}$ & pH \\
\hline \multicolumn{2}{|c|}{ T0 } & 29.51 & 4.10 & 4.62 & 4.74 & 4.15 & 23.55 & 79.84 & 3.59 \\
\hline \multicolumn{2}{|c|}{ T1 } & 32.72 & 5.65 & 5.65 & 5.58 & 5.31 & 23.50 & 83.25 & 3.54 \\
\hline \multicolumn{2}{|c|}{ T2 } & 35.62 & 6.41 & 5.85 & 5.81 & 5.71 & 21.98 & 81.25 & 3.53 \\
\hline \multicolumn{2}{|c|}{ T3 } & 34.25 & 6.84 & 6.51 & 6.25 & 6.38 & 22.12 & 81.63 & 3.48 \\
\hline \multicolumn{2}{|c|}{ T4 } & 35.32 & 6.90 & 6.82 & 6.42 & 6.50 & 21.85 & 84.59 & 3.50 \\
\hline \multicolumn{2}{|c|}{ T5 } & 32.24 & 7.28 & 7.21 & 6.74 & 6.77 & 23.41 & 82.08 & 3.54 \\
\hline \multicolumn{2}{|c|}{ T6 } & 35.24 & 7.38 & 7.28 & 6.94 & 6.94 & 21.26 & 83.70 & 3.51 \\
\hline \multicolumn{10}{|c|}{ Storage Interval Means } \\
\hline \multirow[t]{7}{*}{ Days } & 0 & 42.95 & 7.61 & 7.51 & 7.28 & 7.2 & 17.64 & 92.80 & 3.61 \\
\hline & 15 & 40.23 & 7.28 & 7.18 & 7.00 & 6.9 & 18.88 & 89.36 & 3.59 \\
\hline & 30 & 37.37 & 6.50 & 6.87 & 6.61 & 6.5 & 20.40 & 86.08 & 3.57 \\
\hline & 45 & 34.05 & 6.52 & 6.44 & 6.22 & 6.1 & 22.10 & 82.44 & 3.54 \\
\hline & 60 & 30.16 & 6.02 & 5.95 & 5.74 & 5.5 & 24.01 & 78.65 & 3.51 \\
\hline & 75 & 26.68 & 5.44 & 5.35 & 5.15 & 5.0 & 26.08 & 75.50 & 3.47 \\
\hline & 90 & 23.45 & 4.77 & 4.65 & 4.48 & 4.3 & 28.55 & 71.52 & 3.44 \\
\hline
\end{tabular}

LSD (0.05) 0.76

\section{Reducing sugar}

The influence of storage interval and treatments on the reducing sugar of guava jam samples are shown in (Table 2). The mean values of reducing sugar increased significantly $(\mathrm{p}<0.05)$ in guava jam during 90 days of storage interval. The observed value of reducing sugars of the guava jam samples from Toto T6 at initial day were 17.74, 17.71, $17.54,17.56,17.65,17.58$, and $17.73 \%$. The 
reducing sugar of the various samples increased gradually 30.92, 29.86, 28.42, $27.65,27.07,26.28$, and $29.67 \%$ during 90 days of storage period. The mean value at initial day was 17.64, which increased to 28.55 during the 90 days of storage interval. Maximum mean value was observed in treatment T0 (23.55), however the minimum mean value of 21.26 was recorded for treatmentT6. The maximum percent increase $(42.62 \%)$ was found for T0, while the lowest percent increase of 33.1 was found in treatmentT6.The statistical analysis showed that reducing sugar of guava jam was significantly $(p<0.05)$ affected by treatments and storage intervals. The analysis of reducing sugar of strawberry jam during storage interval showed an increasing trend [40], hence justifying the present results. Similarly, the reducing sugar of apricot jam also increased significantly during storage period $[24,31,41]$ found that the reducing sugar of grape and apple marmalade increased from 16.55 to 31.36 during keeping period. The raise in the reducing sugar is caused by the conversion of sucrose to glucose and fructose, due to temperature and acidic condition [18] observed increase in reducing sugar content during storage period reported by $[42,43]$.

\section{Non-reducing sugar}

The influence of treatments and storage interval on non-reducing sugar contents of Color

The effect of both storage period and treatments on color score of jam samples are shown in (Table 2). The sensory panelist scores for color of guava jam decreased significantly $(\mathrm{p}<0.05)$ during the storage time. At initial day, the sensory score for color of the samples from T0 to T66.5, 6.8, $6.9,7.5,7.5,7.7$ and 7.9, which decreased substantially to $1.4,3.4,4.1,4.9,5.2,5.6$, and 5.8, respectively throughout storage intervals. The mean score of color at initial day of storage was 7.2, which decreased to guava jam showed in a (Table 2). It was found from statistical analysis that the value of non-reducing sugar of the jam reduced considerably $(\mathrm{p}<0.05)$ during 90 days of storage interval. The observed value from T0 to T6of non-reducing sugar at initial day was 40.4, 42.1, 43.2, 43, 44.1, 42.28, and 45.63\%, which decreased gradually to $19.3,23.32$, $26.62,23.65,25.8,21.43$, and 24.09 $\%$ respectively. The mean value for nonreducing sugar at initial day was observed to be 42.95 , which further decreased to 23.45 at 90 days. T6 showed the maximum mean value (35.32) among the treatments, while T0showed the minimum value $(29.51)$. The sample T0showed the maximum percent decrease $(52.22 \%)$ in non-reducing sugar, which is followed by the sample T1 $(44.60 \%)$. The present results are in close agreement with the findings of [40], who found a decline in the non-reducing sugars (44.64-32.35) of the strawberry jam during storage period. A decreased in non-reducing sugar was also obtained in grape and apple marmalade throughout the storage period [24]. Similarly, [20]also observed a decline in non-reducing sugar in pear apple jam [39] prepared a value added product of olive apple blend jam and found a decreased in nonreducing sugar caused by conversion of sucrose to glucose and fructose and inversion of sucrose in the presence of citric acid and heat.

4.34. The maximum mean value for color was observed in T6 (6.94) while minimum value of was recorded for T0 (4.15). The highest \% decreased was observedT0 $(78.41 \%)$ followed by T1 $(50.00 \%)$, while the minimum \% decreased was noted inT6 (26.58\%) followed by T5 (27.27\%).Storage intervals and treatments significantly $(\mathrm{p}<$ 0.05 ) affect the color of guava jam during storage interval. Similarly, [32] investigated that color score decreased from 9.00 to 7.00 in strawberry jam during storage. The color of food product is the most important 
parameters regarding consumer's opinion. During storage, the color of product is significantly degraded [13]. Decline in color score may be due to degradation of ascorbic acid and enzymatic browning.

\section{Taste}

The (Table 2) shows the effect of treatments and storage on taste of guava jam samples. The statistical data representing the panelist scores for taste of jam reduced considerably $(p<0.05)$ during storage interval. The sensory score for taste of guava jam at initial day from T0to T6 were 6.2, 6.9, 7.6, 8.1, 8, 8.2, and8.3, which gradually decreased to a lower score of $1.4,4.1,4.9,5.3,5.4,6.1,6.2$, during the storage interval of 90 days. The mean taste scores at initial day of storage were found 7.61, which substantially decreased to 4.77. The highest mean score for taste was observed at T6 (7.38), while the lowest score was observed at T0 (4.1). The maximum decrease of $77.41 \%$ was observed by T0 which was followed by T1 (40.57), while minimum decrease of 25.30 was observed by T6, followed by T5 (25.60). The observed values revealed that treatments and storage intervals had a significant impact on taste of guava jam samples during the keeping period the present results are in accordance with the work of [15], who investigates decrease in taste scores of apple jam from 8.60 to 5.90 throughout 90 days. However, recorded a decline in the taste scores of watermelon and lemon jam during five month of storage period. Decline in taste score might be due to fluctuations in acids or decrease in $\mathrm{pH}$ [2].

\section{Texture}

(Table 2) shows the effect of treatment and storage interval on texture of carrot and apple blended jam. The mean sensory scores for texture of the jam decreased significantly $(\mathrm{p}<0.05)$ on both treatments and storage intervals. The panelist scores for texture of guava jam from t0 to t6 at day one were 6.8, 6.9, 7, 7.4, 7.5, 7.6, and 7.8. However, during storage interval texture of the jam samples decreased gradually to $1.7,3.9,4.2,4.8,5.2$, 5.7, and 5.9. Mean texture score observed at initial day of storage was found 7.28, which decreased to 4.48 throughout the storage period of 90 days. The highest mean score observed of 6.94 was obtained by $t 6$, while the lowest score of 4.74 was observed $\mathrm{T} 0$. The maximum percent decrease in the texture of the guava jam was recorded in to (75) followed by $\mathrm{T} 1$ (43.47), while minimum decrease of $24.35 \%$ was observed at t6 followed by T5 (25) the statistical analysis of the samples showed that texture of guava jam differed significantly $(\mathrm{p}<0.05)$ both by treatments and storage intervals. The present findings are in accord with observed values of [44], who observed a gradual decrease in the texture properties of strawberry jam. The present value for texture is found to be slightly lower than the findings of [24], who observed a decrease in the value of texture of grape and apple marmalade during storage. Similarly,[25] analyzed decrease in texture score from 9.00 to 6.70 in apple jam. Texture consists of those properties of product which is judges visually or by touch.

\section{Overall acceptability}

(Table 2) shows the effect of treatments and storage interval on overall acceptability of guava jam. The overall acceptability scores of the jam reduced considerably $(\mathrm{p}<0.05)$ on both treatments and storage. The overall acceptance score of guava jam at first day from T0 to T6 were 6.7, 6.9, 7.1, 7.7, 7.9, 8.1, and 8.2 , which decline gradually to $1.5,3.9$, $4.3,5.1,5.5,6.1$, and 6.2 respectively during the storage period of 90 days. The mean overall acceptance score at initial day was 7.51, which decrease to 4.65 during the storage time of 90 days. The highest score of 7.28 was observed at T6, while minimum score of 4.62 was observed at $t 0$. The highest percent decrease of 77.61 was recorded at t0 followed by t1 (43.47), while minimum percent decrease of 24.39 was recorded at T6 followed by T5 (24.69) the overall 
acceptability of carrot and apple blended jam is significantly $(\mathrm{p}<0.05)$ influenced by treatments and storage interval (appendix $\mathrm{x}$ ). The overall acceptance of grape and apple marmalade decreased from 8.8 to 7.96 during the storage interval, thus supporting the present results [32] also examined similar results of decreasing trends (9.00 to 7.00) in overall acceptability in fruit jam. Similarly, [45] found decline in the overall acceptability of lemon and watermelon jam.

\section{Conclusions}

Jam of Guava was prepared with different pectin ratio. Which was physico-chemically and sensory evaluated for 3 months. During storage different parameter were under study for the Guava fruit jam. The mean value of TSS of different treatment of guava jam gradually rises from 67.4 to 69.71 . The maximum percent decreased was observed in treatment T0 $(5.94 \%)$ while the minimum percent decreased was founded in treatment T6 $(3.87 \%)$ during 90 days of storage. The mean value shows the significant $(\mathrm{P}<0.05)$ increased in acidity from 0.72 to 0.89 during 90 days of storage 。 In Ascorbic acid maximum percent decrease was found in treatment T4 (23.87\%) while minimum percent decrease was observed in treatment T6 (20.90). The influence of storage interval and treatments on the reducing sugar of guava jams samples. The mean values of reducing sugar increased significantly $(p<0.05)$ in guava jam during 90 days of storage interval. The influence of treatments and storage interval on non-reducing sugar contents of guava jam. It was found from statistical analysis that the value of nonreducing sugar of the jam reduced considerably. The result obtained from different parameter that treatment $\mathrm{T}_{6}$ Guava jam having pectin ratio (1.2) followed by $\mathrm{T}_{5}$ Guava jam having pectin ratio (1.0) were of superior acceptability among the guava jam samples during physicochemical and sensory evaluation. The overall acceptance of grape and apple marmalade decreased from 8.8 to 7.96 during the storage interval.

\section{Authors' contributions}

Conceived and designed the experiments: TU Rahman \& S Wahaab, Performed the experiments: T Rahman \& N Tahir, Analyzed the data: Amanullah \& N Tahir, Contributed materials/ analysis/ tools: AU Rahman, A Khan \& A Tahir, Wrote the paper: TU Rahman \& N Tahir.

\section{References}

1. Babalola SO, Ashaye OA, Babalola AO \& Aina JO (2002). Effect of cold temperature storage on the quality attributes of pawpaw and guava leathers. African J of Biotechnol 1(2): 61-63.

2. Burkill HM (1997). The Useful Plants of West Tropical Africa. 2nd Edition, Vol 4 (Families M-R), Royal Botanic Gardens, Kew 2nd Edition 4: 648.

3. Tariq K, Sana K \& Mehnaz S (2015). Functional Properties and Preparation of Diet Apricot Jam. J Food Process Technol 6: 475 .

4. Agricultural statistics of Pakistan (201112). Government of Pakistan ministry of national food security and research (economic wing) Islamabad.

5. Garg NP, Yadav N, Goel AK, Bhattacharjee S, Rajan \& Rajesh K (2007). Screening of acidic guava accessions for cider preparation. International Guava Symposium Acta Hort No. 735. Inter Society of Horti Sci.

6. Ayub, Alam Z, Javid U, Muhammad M \& ALI KK (2005). Effect of non-nutritive sweeteners, chemical preservatives and antioxidants on microbial and sensory characteristics of dehydrated guava. $J$ Sci \& Tech Uni of Peshawar 2(1).

7. Ismail M, Minhas F, Khanum VM, Sahana \& Sowmya C (2012). Antibacterial activity of leaves extract of guava (psidiumguajava). Inter $J$ Res Pharma Biomed Sci 3(1): 1-2.

8. Ashaye OA, Babalola SO, Babalola AO, Journal O, Aina \& Fasoyiro SB (2005). Chemical and organoleptic 
characterization of pawpaw and guava leathers. World J Agri Sci 1(1): 50-51.

9. Morais TB, Diegues ACB \& Sigulem DM (2003). The use of light microscopy in a study of extraneous matter and authenticity of guava, strawberry and grape jam. J Food control 15: 497-499.

10. Kaur S, BC Sarkar, H K Sharma \& C Singh (2009). Optimization of enzymatic hydrolysis pretreatment conditions for enhanced juice recovery from guava fruit using response surface methodology. Food Bioprocess Tech 2: 96-100.

11. Jawaheer B, Goburdhun D \& Ruggoo R (2003). Effect of processing and storage of guava into jam and juice on the ascorbic acid content. Plant Foods for Human Nutrition 58: 1-12.

12. Jain PK \& Asati PK (2004). Evaluation of guava cultivars for pulp preparation. $J$ Food Sci Tech 41(6): 684-686.

13. Gimenez J, kajda P, Margomenou L, Piggott JR \& Zabetakis I (2001). A study on the colour and sensory attributes of high-hydrostatic-pressure jams as compared with traditional jams. J Sci Food and Agric 81: 1228-1234.

14. Sogi DS \& singh S (2001). Studies on bitterness development in kinnow juice, ready- to-serve beverage, squash, jam and candy. J Food Sci and Technol 38(5): 433438.

15. Ozdogan F \& Yilmaz E (2011). Evaluation of green tomato jams prepared from two kinds of tomatoes. Akademik Gida 9(2): 19-25.

16. Kirca A, Ozkan M \& Cemeroglu B (2007). Storage stability of strawberry jam colour enhanced with black carrot juice concentrate. J Food Proc and Pres 31(5): 531-545.

17. AOAC (2012). Official methods of analysis. Association of official analytical chemists. $19^{\text {th }} \mathrm{ed}$. Gaithersburg, Maryland 2: 20877-2417.

18. Steel RGD, Torrie JH \& Dicky DA (1997) .Principles and Procedures of Statistics, A Biometrical Approach. 3rd Edition,
McGraw Hill, Inc Book Co, New York, 352-358.

19. Desrosier NW \& Desrosier JN (1978). The technology of food preservation. Fourth edition. Avi publishing Co Inc Westport, Connecticut.

20. Singh SUS, Shivhare J, Ahmed GSV \& Raghavan (1999). Osmotic concentration kinetics and quality of carrot preserve. $J$ Food Res Int 32: 509-514.

21. Safdar MN Amer M, Tabssum H, Nouman S, Samina K \& Muhammad A (2012). Storage studies of jam prepared from different mango varieties. Pak $J$ Nutr 11(7): 555-561.

22. Muhammad

A, Yasir D, Muhammad AZ \& UllahJ (200). Development of diet jam from apple grown in swat (NWFP). Sarhad J Agric 24(3): 461-467.

23. Muhammad

A, Yasir D, Muhammad AZ \& Ullah J (2009). Organoleptic evaluation of diet apple jam from apple grown in Swat valley. Sarhad J Agric 25(1): 81-86.

24. Ehsan EB, Naeem ZP, Javid A \& Nazir A (2003). Development, standardization and storage studies on grape fruit apple marmalade. Pak J Food Sci 13(4): 11-15.

25. Rathore HA, Masud T, Sammi S \& Soomro AH (2007). Effect of storage on physic-chemical composition and sensory properties of mango variety dosehari. Pak J Nutr 6: 143-148.

26. Kocher GS \& Pooja (2011). Status of wine production from guava (psidiumguajaval.) A traditional fruit of India. African J Food Sci 5(16): 851-860.

27. Hussain I \& Shakir I (2010). Chemical and organoleptic characteristics of jam prepared from indigenous varities of apricot and apple. World J Dairy and Food Sci 5(1): 73-78

28. Fu JT \& Muhammad AR (2001). Rheology and structure development during gelation of low-methoxyl pectin gels: the effect of sucrose. Food Hydrocolloids 15(1): 93-100. 
29. Jain Pk \& Prabhat KN (2007). Processing of pulp of various cultivars of guava (Psidiumguajaval) For leather production. Agri Eng Int 9: 1-9.

30. Miguel GO \& Martin B (1999). Influenence of fruit dietry bre addition on physical and organoleptic charactaristicsof straw jam. J Food Eng 41: 13-21.

31. Ajenifujah S \& Aina J (2011). Physicochemical properties and sensory evaluation of jam made from black-plum fruit. Afr $J$ of Food Agri Nutr and Devolpment 11(3).

32. Kocher GS \& Pooja (2011). Status of wine production from guava (Psidiumguajaval) A traditional fruit of India. African J Food Sci 5(16): 851-860.

33. EhsanEBNaeem ZP, Ghafoor A \& Bahtti MS (2002). Development, standardization and storage studies on watermelon lemon jam. Pak J Food Sci 12(3-4): 21-24.

34. Singh SUS, Shivhare J, Ahmed GSV \& Raghavan (1999). Osmotic concentration kinetics and quality of carrot preserve. $J$ Food Res Int 32: 509-514.

35. Shakir I, Imtiaz H, Alam Z \& Durrani Y (2009). Sensory evaluation and microbial analysis of apple and pear mixed fruit jam prepared from varieties grown in Azad Jammu and Kashmir. World J Dairy and Food Sci 4(2): 201-204.

36. Khan RU, Afridi SR, Ilyas M, Sohail M \& Abid H (2012). Development of strawberry jam and its quality evaluation during storage. Pak J Biochem Mol Biol 45(1): 23-25.

37. Souad AM \& Parveen J (2012). Physicochemical Analysis of Jam Preparations from Watermelon Waste. International Conference on Chemical,
Environmental and Biological Science (ICCEBS'2012) Penang, Malaysia.

38. Renna MB, Pace M, Cefola P, Santamaria F, Serio \& Gonnella M (2013). Comparison of two jam making methods to preserve the quality of colored carrots. $J$ Food Sci and Tech 53: 547-554.

39. Wasif S, Arsalan K, Alam Z, Muhammad AK, Falak NS, Noor UA, Muhammad A, Said W, Ali M \& Sher HK (2015). Quality evaluation and preparation of apple and olive fruit blended jam. Global journal. Medical Research: L. Nutrition and Food Sci 15(1): 15-21.

40. Shakir I, Imtiaz H, Alam Z \& Durrani Y (2009). Sensory evaluation and microbial analysis of apple and pear mixed fruit jam prepared from varieties grown in Azad Jammu and Kashmir. World J Dairy and Food Sci 4(2): 201-204.

41. Clarke MA (1997). Sugars in food processing. Inter J Sugar 99(1): 14-26.

42. Riaz MN, Mohyuddin G \& Al-Haq MI (1999). Physical, chemical and sensory characteristics of jams made from fresh and frozen strawberries. Pak J Arid Agric 2(1): 51-60.

43. Khan RU, Afridi SR, Ilyas M, Sohail M \& Abid H (2012). Development of strawberry jam and its quality evaluation during storage. Pak J Bio Chem Mol Biol 45(1): 23-25.

44. Wang QI, Pagan, Jordi \& Shi J (2002). Pectin from fruits. Funct Foods Bio Chem \& Processing Aspects 2: 263-309.

45. Vidhya R \& Narain A (2010). Development of preserved products (jam and fruit bar) from under exploited wood apple "limoniaacidissima" fruits. African J of Food Sci and Technol 1(2): 051-057. 